\title{
The Role of Project Management in the success of Small Businesses
}

\author{
Bazhar Kawani, Kahi Ilham Abdal \\ Technical Finance and Accounting Dep. Erbil Polytechnic University
}

\begin{abstract}
This paper shows the importance and effect of project management on the successes of the small businessproject. Additionally, the key factors that lead to the success and make the project to reach the plannedtarget, as well as to the continued successes of the project life through studying the development of projectmanagement history and highlights what can lead to this success for the projects in the small business. Thecompetitive in the market is very difficult to survive, but it is obvious that big dreams start from small steps.
\end{abstract}

\section{Introduction}

Nowadays, it has been very difficult for any businesses to survive in this competitive environment, especially the small business because they need to grow and gain market share, gain competitive advantages and attract customers. As a result, their work is important and is considered to play a crucial role to their success. Additionally, it is essential for small businesses to adopt project management in order to improve their performances. The project management is playing an important and strategic role in developing small businesses, whether it is effectively actualizing the ideas or controlling and monitoring the resources (Florincuţa and Thongsawai, 2010). However, in the recent academic view in corporate management and for how long the development is handled, some views were interesting because authors such as Bengtsson et al. (2007) suggest that small and large businesses should adopt a flexible structure which would be able to change and develop depending on the market need, without having a fixed structure (Florincuţa and Thongsawai, 2010 cited in Bengtsson et al., 2007). As the world is moving towards technology development, globalisation era and the business world having become more competitive, there has been a need for effective project management, especially for small businesses since it has limited resources and need to grow. As a result, the aim of this report is to critically analyse the role and success of project management in small businesses. The reason behind choosing this route and topic is due to the importance of the project management to the consulting project, it was a crucial factor to our successes in the project.

\subsection{Conceptual Framework:}

It is important for any research to have a conceptual framework to put all the concepts together as a diagram and show the outline of the research which enhances the reader understands (Fisher, 2010). First, the researcher's ideas were to search about the successfulness of project management, and many resources have been found in order to do the literature after consulting the supervisor; his advice was to focus on one area and narrow down the topic and his ideas played an essential part to this research as his suggestions was to focus on project management in small business. As a result, the researcher has searched more effectively for this topic and the outline is as follows: first the definition of small business and project management is discover; Second, the historical development of project management; Then, the historical development of the role of project manager with the improvement of project management structure have been explored. Moreover, the role and the importance of project management in small businesses; Next, the factors affecting the success of project management in small businesses; followed by the important factors affecting and leading to the failure of project management in small business. Finally, the conclusion, limitation and recommendations will be discussed. There were a wide range of other concepts of project management to discover but the research focus on the most relevant one to his research. 


\section{Definition of small business and Project Management:}

The definition for small business varies and differs from one country to another. It is a good idea to focus on the definition of international labour organisation (ILO), which defines small business as a small entity or project which employ between 10 to 99 workers; it is emphasized on the number of workers and mentioned that projects with more than 99 are considered as a large project. According to Alhajeri (2012) the majority of small businesses work with small fixed amount of capital or they might work without any fixed capital, small businesses employ a low level of efficiency. Additionally, the small business has irregular income which provides unstable job opportunities and does not register with government authority; they do not have any official statement and are considered as a non-official sector (Alhajeri, 2012 cited in ILO, 1991). Moreover, the committee on economic development in the USA has defined small business based on some specifications and if the business fulfils two of these conditions it can be defined as a small business. The conditions as follows: first independent management, meaning the project owner is the project manager; second, the project has been funded by individual owners or small group of owners; third, the business workers and owner live in one community. Although the market may not be local, the business should be conducted locally. Furthermore, the project size is small in comparison to relative industry (Alhajeri, 2012 cited in AlMahrook \& Mokamla, 2006). After studying the different definitions for small business, it is obvious that small businesses have taken many academics' and practitioners' attention and this due to its importance to the economy (Alhajeri, 2012). In order to manage a small business more efficiently and effectively there is a need for having a good project management structure to survive in this competitive environment.

Project management is an important process which aids the monitoring and evaluation of the resources. Since 1950, an attempt has been taken by Oisen to define project management, others tried to define project management, but the definition differs from one country to another. Some researchers, such as Turner, have defined project management as the art of Science, and its vision are converting the objects to reality. However, this definition context has been criticised because it does not refer to the measurement of the project management. Hence it is difficult to agree on one definition (Atkinson, 1999). Besides, the British Standard for project management 1996 has defined project management as follows:

The planning, monitoring and control of all aspects of a project and the motivation of all those involved in it to achieve the project objectives on time and to the species cost, quality and performance (Atkinson, 1999 cited in The British Standard for Project Management, 1996: P338).

From this definition, it is obvious that project management is an essential process for managing the business resources and project management success can be measured by the quality, time and cost of the project. As a result, project management will play an important role in improving the small business's performance through clear assessment and careful managing of the strategies and human resources (Florincuţa and Thongsawai, 2010).

\section{Historical development of project management:}

The project management practice is related to the Egyptian epoch in the mid-1950, organisations used to have formal project management tools and techniques for complex projects. The origin of modern project management comes from two parallel, but different, problems in planning and controlling the project and has been introduced in the United States. Furthermore, the development of modern project management can be divided into four periods. The first period, prior to 1958, has been named as craft system to human relations, which has witnessed the evolution of technology and this helped project management in various ways. For example, the automobiles and telecommunications have shortened the project schedule; the automobiles provide the business with effective resource allocation and mobility, whereas the speed of communication has increased during the development of telecommunication system (Azzopardi, 2013). Additionally, Henry Gantt has created the Gantt chart to develop the work breakdown structure. The second period, 1958-1979, named as an application of management science, several project management tools were introduced, such as program evaluation review technique (PERT) and project planning and scheduling 
(PPS). Additionally, many software programmes have been introduced to facilities the project management work. Thirdly, 1980-1994, the period known as production centre human resources, has witnessed the revolution of information management by introducing the PC (personal computer); this development has assisted the project management in saving the costs and increasing the efficiency. Finally, since 1995 to present time, period named as creating new environment, the world witnessed further development of technology and internet which facilitate the work of project management even further (Azzopardi, 2013). It is obvious that project management is a historical concept as it has been used to facilitate business workload, by using the resources effectively and this concept has been developed through the advancement of technology. Additionally, after discussing the evolution and development of project management, it is essential to understand the role of evolution of project management to enhance the role of project manager in organisation, thus this will aid businesses through efficient usage of their resources and this will be discusses of the next part.

\section{The historical development of the role of project manager with improvement of project management structure:}

The first period of project management organisation started in 1984-1992, pro-PMO, this period perceived an important development which was hiring the first project managers as a result of new market requirements. The project management structure is simple and the project manager works with technical people. Second, during the period named Business PMO, from the 1992-1996, the PMO was implemented with new business opportunities. The relationship with clients becomes the responsibility of PMO which gave a project manager a strategic role (Aubry et al., 2008). The third period was Technical PMO, 19961998; during this period the head officer changed responsibility and took the role of managing the relationship with clients. However, this period faced major changes in technology in the centre of R\&D, which is heavily relying on technology, hence during this period, the complexity of this process increased. This resulted in the project management to become more powerful and for the first time, the project manager become a part of it. Next, the fourth period was Business Unit PMO, 1998-2004, saw a major change but the centre of R\&D remained unchanged until 2004. Four business units were responsible for the centre of R\&D and each one of them has its own structure of project management. Finally, the fifth period 2004-2005, Consultant PMO developed after three years of difficulties in the financial globe, the results are encouraging and the organisation continued focusing on the R\&D activities to optimize the operation side of their business. The project management during this period was completely centralised, the project managers role in the organisation was assigned as the consultant; their role was to look at business results while, at the same time, looking after the project processes (Aubry et al., 2008). It is obvious that the project management structure and the role of project manager have changed throughout the years with the market development. Small businesses and any other businesses should use these developments as an opportunity and take advantage of the project management and project manager development which will lead to increasing their innovation in accordance to their capability and resources, these factors are important especially for small business due to their need to grow in the market.

\section{The roles and significance of project management in small business:}

It is essential for any business to have an appropriate structure or framework of project management in order to monitor usage of the resources effectively and efficiently, to achieve the best results in their business. Some authors, such as Bengtsson et al. (2007), support the idea of having a formal structure in order to enhance sustainability, which makes it clear that structural arrangements are applied by most businesses as it leads to the administration of their resources. However, the same author has argued that the structural arrangements should not be seen as a counterpoint for flexibility, but it should show the interconnection between the firms and individuals. This lead the authors to contemplate those small businesses take actions to reach their aims through the context of project management (Florincuţa and Thongsawai, 2010). So, it is obvious that project management play a role in facilitating the small businesses to reach their objectives. As it has been discussed by some authors, such as Kemp (2006), that project management is more important for small businesses rather than big business (Florincuţa and Thongsawai, 2010 cited in Kemp, 2006). Additionally, Kemp argued that large businesses have more flexibility in using their resources in comparison 
to small businesses. From the owner's point of view and capital provider, project management has great impact on the successfulness of small businesses (Florincuţa and Thongsawai, 2010). Besides, as a specialist in project management and owner of small businesses, Kemp has emphasized on the importance of project management in the small business by asserting that small businesses need project success as they cannot afford to waste their money and resources like a large company can (Florincuţa and Thongsawai, 2010). Additionally, through this discussion, it is clear that project management aids the success of small businesses and is essential for using the resources in a more effective and efficient way.

\section{The important factors affecting the project management success in small business:}

There are many factors affecting the project's success and each author classifies them differently from each other. Belout and Gauvreau (2004) have discussed the Pinto and Prescott's ten success factors which are: project schedule, client consultation, technical tasks, client acceptance, monitoring and feedback, communication, trouble-shooting, management support and personal (recruitment and training programme). If these factors are well managed then the project will be successful. Belout and Gauvreau have concluded their research by declaring on the role of human resources in the success of the project (Belout and Gauvreau, 2004; Hyvari, 2006). However, other researchers, such as Shenhar et al., 2001 have discovered a multidimensional strategy and factors which affect the successfulness of any project in any sector. Additionally, the first dimension for project success is meeting time, budget and requirement goals; after an examination by Shenhar et al, it appears that these factors are critical to a project's success (Shenhar et al., 2004). Managing a project is associated with special context, as well as having the ability to coordinate and control the collaboration between different stakeholders, and is directly related to the coordinator: skills, enthusiasm and top-level management commitment (Florincuţa and Thongsawai, 2010 cited in Autio and Klofsten, 1998; Pol et al., 2007). In addition, the crucial factors for the success of any project management in small business are strategy and human resources. Strategy and strategic orientation, and this includes fundamental politic, goals and directions with regard to small business, the capability innovation and the speed of implementing new projects; are all essential for the success of small businesses and their survival in this competitive environment. Besides, emphasis on the goals and strategy are important for developing small business, in addition to the scale of time, budget, planning and scheduling activities (Florincuţa and Thongsawai, 2010; Raymond and Bergeron, 2008). In addition, some authors such as Munns and Bjeirmi, 1996, have stated that quality, cost, control of time and planning are the successful techniques for implementing a successful project; in both, small and large businesses, and these techniques can be used as an assessment tools for project success or failure (Munns and Bjeirmi, 1996).

\section{The important factors affecting the project management failure in small business:}

As there are many factors affecting the project management success, there are many factors which lead to project management failure in small business. According to Munns and Bjeirmi (1996), there are some factors affecting the successfulness of project management and can lead to its failure, and they are: inadequate basis for project, selecting the wrong person as a project manager, unsupportive top management, inaccurate defined tasks, lack of project management tools and technique, miss-usage of project management technique, miss-planned project and lack of commitment to the project. All these things lead to the failure of project management in businesses and therefore lead to business failure as well (Munns and Bjeirmi, 1996). However, some authors like Preston (1997) have argued that there are two types of factors affecting and consequently leading to the failure of small business project management which are internal and external. The internal causes are poor management capability, unstable and inefficient management, lack of experience, lack of attention, fraud and disaster where the external factors are highinterest rate, inflation and unemployment, taxes, competitions and government rules. From these factors it is evident that all the internal factors which lead to small business failure are related to poor management and planning; ineffective project management and thus can be managed by having effective project management. External factors, unfortunately, cannot be managed or control by small business but its influences can be reduced by having a risk assessment schedule and understanding, which will help with the reduction of these types of risks. This is also achievable through an effective project management (Alhajeri, 2012). 


\section{Conclusion:}

To sum up, after discussing the role of project management in small business success, it is clear that project management play an essential role due to its techniques and tools which enhance: productivity, capability and the best usage of resources which lead to the growth of the business, expanding market share, gaining competitive advantages, etc. Effective project management have factors leading to the success of small business, in some cases having project management without understanding its purpose lead to ineffective project management and as a result small business may fail. So, it is important to have a good understanding of project management concepts, techniques and tools which will gives small businesses great advantages, especially as it has limited resources and need to grow as fast as they can to get the customer attention and accordingly gaining market share.

\section{Recommendation:}

Similar to any other areas of project management, researcher have a gap in their research area, either in the data (case studies) or in some areas which have not taken the attention of the researcher, or has limited research. To solve the problem with research data, there is a need for more in-depth analysis of the case studies, studies in the processes and the studies in the real-time because these types of data will enhance the understanding of the fundamental issues in the project management and project organisation (Soderlund, 2004). Besides, Soderlund (2004) argued that little attention has been paid to the actual work and performance of project managers and the project management unit, which is considered as a gap and requires research to discover: role, cycle and function of project management unit. The project management research is important to build the theoretical background of this area and this will lead to the improvement, not only on the single projects but also, in the effectiveness of many firms and entire sector (Soderlund, 2004). Another noticeable gap in the research area is there are no many sources about project management in small business. After identifying the gap in the project management area and raising its awareness it is important to do further research in the missing areas such as considering the role of project management and project manager in small business.

\section{Reference}

[1] Alhajeri, A., S.B.J. 2012. The Financing and Success Factors of Small Business in Kuwait [online]. Ph.D. thesis, United Kingdom: University of Portsmouth. Available at: https://researchportal.port.ac.uk/portal/files/5315086/Small_BusinessPDF.pdf .

[2] Atkinson, R. 1999. Project management: cost, time and quality, two best guesses and a phenomenon, its time to accept other success criteria. International Journal of Project Management [online].17
(6).
PP.
337-342.
Available
at:

https://wiki.rit.edu/download/attachments/118458642/David\%20Lewis\%20\%20Project\%20Management.pdf?api=v2

[3] Aubry, M. Hobbs, B. and Thuillier, D. 2008. Organisational project management: An historical approach to the study of PMOs on projet. International Journal of Project Management [online].26. PP.38-43. Available at: http://isiarticles.com/bundles/Article/pre/pdf/3186.pdf.

[4] Azzopardi, S. 2013. The Evolution of Project Management [online]. Project Smart. Available at: https://www.projectsmart.co.uk/evolution-of-project-management.php

[5] Belout, A. and Gauvreau, C. 2004. Factors influencing project success: the impact of human resource managementachieving. International Journal of Project Management [online]. 22. PP.1-11. Available https://elearning.unite.it/pluginfile.php/55156/mod folder/content/0/7.3.1\%20Paper.pdf?forcedownload=1 at: FISHER, C. 2010. Researching and Writing a Dissertation: An essential guide for business students. $3^{\text {rd }}$ edition. Pearson Education Limited.

[6] Florincuta, G. R. and Thongsawai, P. 2010. SUPPORT FOR SMALL BUSINESS AND ITS PERCEIVED INFLUENCE ON PROJECT SUCCESS A study of projects of small businesses in a Swedish Science Park [online]. Master Thesis, Sweden: Umeå University. Available at: https://cloud.jorgesilva.com.br/cdn/B01K95DRMS-support-for-small-business-its-perceived-influence-onproject-success-a-study-of-projects-of-small-businesses-in-a-swedish-science-park-by-roxandra-giorgianaflorincuta-2010-08-19.pdf 
[7] Holden, T., M. and Lynch, P. 2004. Choosing the Appropriate Methodology: Understanding Research Philosophy [online]. Available at: https://repository.wit.ie/1466/

[8] Hyvari, I. 2006. Project management effectiveness in project-oriented business organizations. International Journal of Project Management [online].24. PP.216 225.Available at: http://isiarticles.com/bundles/Article/pre/pdf/3055.pdf

[9] Munns, K. A. and Bjeirmi, F. B. 1996. The role of project management in achieving project success. International Journal of Project Management [online]. 14 (2). PP. 81-87. Available at: https://www.sciencedirect.com/science/article/abs/pii/0263786395000577

[10] Raymond, L. and Bergeron, F. 2008. Project management information systems: An empirical study of their impact on project managers and project success. International Journal of Project Management [online]. 26. PP. 213-220. Available at: https://www.sciencedirect.com/science/article/abs/pii/S0263786307000981

[11] Shenhar, J. A. Dvir, D. Levy, O. and Maltz, C. A. 2001. Project Success: A Multidimensional Strategic Concept. Long Range planning [online]. 34. PP.699-725. Available at: https://irecanati.tau.ac.il/sites/nihul.tau.ac.il/files/media_server/Recanati/management/hurvitz/forms/ articles/Dov\%20Dvir/15.\%20Proj\%20Success\%20Multi\%20Dim\%20LRP\%202001.pdf

[12] Soderlund, J. 2004. Building theories of project management: past research, questions for the future. International Journal of Project Management [online]. 22. PP. 183-191. Available at: https://fenix.tecnico.ulisboa.pt/downloadFile/1689468335567429/1\%20Tuesday\%20-

\%20Building\%20theories\%20of\%20project\%20management.pdf 